Acta vet. scand. $1959,1,67-73$.

From the Department of Pharmacology, Veterinary College, Helsinki, Finland.

\title{
DIGITALIS INACTIVATION IN VITRO DUE TO RUMEN MICROBES FROM SHEEP
}

\author{
By
}

H. Westermarck.

\section{INTRODUCTION}

The effect of digitalis in ruminants has been established (Westermarck 1956). The activity is delayed, however, when digitalis is given orally, but it can be achieved with about ten times larger doses than those which are effective when administered intravenously. Digitalis is probably decomposed in the rumen by the action of the rumen microbes. Thus variations in the microbes in sheep on different feeds may explain the contradictory experiences obtained with peroral digitalis therapy. The inactivating properties of rumen fluid from sheep on different feeds was therefore investigated.

\section{MATERIALS AND METHODS}

\section{1) Rumen fluid.}

Rumen fluid was taken using a stomach tube from four sheep on different feeds. The type of feed was changed for two of them during the experiment.

Sheep I was fed cattlefeed in abundance for 14 days and later aureomycin for 2 days only, sheep II first cattlefeed and then hay, after 3 days aureomycin was added to one part of the sample, sheep III straw only and sheep IV hay only.

2) Methods of studying rumen microorganisms and their activity.

Rumen samples were filtered through a cheese cloth and the $\mathrm{pH}$ determined in a Beckman $\mathrm{pH}$ apparatus. The number of fungi and infusoria was determined microscopically and the cellulose digestion was estimated according to Hoflund. In this method 
the time when the rumen microbes of a sample kept at $37^{\circ} \mathrm{C} \mathrm{had}$ digested through a cotton thread was considered the cellulose digestion time. Glucose fermentation was determined in a fermentation tube.

3) Preparation of digitalis-rumen fluid mixture.

The rumen fluid was mixed with digitalis immediately after filtration. To each $100 \mathrm{ml}$. of rumen fluid 25 units of digitalis, in form of a concentrate, were added. The effect of one milliliter of the mixture obtained had an effect equal to 0.2 digitalis units of the 1936 standard.

The mixture was then centrifuged at $2000 \mathrm{rpm}$ for half an hour and a part of the supernatant fluid was injected into four guinea pigs. The supernatant fluid containing digitalis was also incubated in anaerobic conditions at a constant temperature of $37^{\circ} \mathrm{C}$ for 48 hours. Digitalis determinations were made at that time and in some cases at 24 and 72 hours too. The same guinea pigs test with 4 guinea pigs was used as performed with fresh digitalis-rumen fluid mixture directly after centrifuging.

Rumen fluid was also incubated without digitalis for 48 hours, 25 units of digitalis was then added and the mixture injected into guinea pigs. The incubated digitalis-rumen fluid mixture was also injected after 48 hours into guinea pigs. Digitalis-rumen fluid samples were stored deepfrozen too and injected after 48 hours into guinea pigs. For controlexperiments fresh centrifuged rumen fluid and digitalis in water solution, 25 units per $100 \mathrm{ml}$ were used.

\section{4) Guinea pig test.}

In the guinea pig test used for determination of the potency, the animals were anesthesized with urethane injected intraperitoneally in a $20 \%$ solution in a dose of $1.75 \mathrm{~g}$. per $\mathrm{kg}$. body weight. This route of administration is considered to give more homogeneous results than the subcutaneous injection in which the activity varies according to the site of injection. The guinea pig falls asleep immediately after an intraperitoneal injection, thus also saving time. Every value in this investigation concerning the effect of digitalis, represents an average of four records.

Alltogether 130 guinea pigs were used in this experiment. The average weight was $453 \mathrm{~g}$. and in no case was the weight more than $500 \mathrm{~g}$. or less than $400 \mathrm{~g}$. 


\section{5) Apparatus.}

The digitalis determinations were made using the intravenous route. Injections were made intrajugularly using an injector which permitted an absolutely constant flow (in this case $0.4 \mathrm{ml}$. per minute). When the heart began to flutter, the speed was cut in half. The heart beat was watched during the whole determination through the opened thorax and artificial respiration was given all the time through a tracheal tube. The injection was started directly after opening of the thoracic cavity.

\section{RESULTS}

The difference between the amount of fluid immediately injected after digitalis being added to the fresh rumen fluid and the amount showing the potency of the incubated digitalis-rumen fluid is considered to be the loss in potency caused by rumen microbes. No significant difference was found between the results obtained when the digitalis-rumen fluid mixture containing 25 IU Digitalis per $100 \mathrm{ml}$. was injected directly after mixing and the results obtained when the same mixture had been stored for 48 hours in the deepfreeze. Thus digitalis cannot be considered to be linked to the food particles to any significant degree. When digitalis was added to fresh rumen fluid $0.57 \mathrm{ml}$. mixture was needed to kill $100 \mathrm{~g}$. guinea pig and after being in the deepfreeze for 48 hours $0.59 \mathrm{ml}$. was lethal. In a second experiment $0.58 \mathrm{ml}$. was the average lethal dose and after deepfreezed $0.63 \mathrm{ml}$. killed $100 \mathrm{~g}$. guinea pig. The results are practically the same.

When all the estimates of digitalis made from the rumen contents immediately after digitalis was added, i.e. from 32 records, the average lethal dose was $0.76 \mathrm{ml}$. per $100 \mathrm{~g}$. of guinea pig instead of $0.82 \mathrm{ml}$. for the same amount of digitalis in water solution. Thus the toxic effect of rumen fluid was so small compared with that of digitalis that it can have no significance when the results of this investigation are evaluated.

No significant amount of digitalis was left in deposits as the lethal dose of rumen fluid alone is found to be about $4.35 \mathrm{ml}$. per $100 \mathrm{~g}$. guinea pig, and of extracts made from the deposits of the rumen fluid-digitalis mixture $4.1-4.9 \mathrm{ml}$. Thus showing that practically no digitalis was left.

The units found on the basis of the lethal dose on guinea pigs were calculated and the results interpreted to correspond to the total original amount obtained by centrifuging. An estimate 
shows that the sheep fed an abundance of cattle teed had a rumen fluid of which, when 20 units were added to $100 \mathrm{ml}$., altogether 19.6 units were recovered. From the sheep which had been given straw alone 19 out of 20 units were found to be active at the time of the first injection. The corresponding amount from the sheep fed aureomycin was 18 units of 20 added.

\section{CONCLUSIONS AND DISCUSSION}

Figures in Table I show that the inactivating properties varied in sheep on various feed. Digitalis was inactivated effectively by rumen fluid from the sheep which was fed cattlefeed in abundance, as the lethal dose decreased by 73.1 per cent or 0.32 units calculated per 100 g. body weight. This means that nearly 2.5 times more digitalis-rumen fluid mixture was needed after incubation for 48 hours to kill a guinea pig than when the digitalis was added to a rumen fluid immediately before injection. Aureomycin was also later fed to this sheep in a daily dose of $35 \mathrm{mg}$. per kg. body weight for two days. At that time the number of fungi and infusoria had decreased by 50 per cent and cellulolysis as well as fermentation had almost ceased. No large infusoria whatever were seen. This sheep became seriously ill but recovered after treatment with fresh fluid. Rumen samples taken when the sheep was ill did not inactivate digitalis at all. The lethal dose before incubation was 0.15 unit per $100 \mathrm{~g}$. of guinea pig body weight and after storage 0.14 units. The rumen fluid, which was second in the effectiveness of inactivation was that taken from the sheep which was fed straw only. The toxicity of the digitalisrumen fluid mixture decreased then and 37.6 per cent of the digitalis added by 0.16 unit per $100 \mathrm{~g}$. Rumen fluid taken from the sheep fed on hay only inactivated the digitalis to the same extent. Rumen fluid from a sheep fed hay and cattlefeed inactivated in 48 hours 20.6 per cent of the digitalis added. After 72 hours the toxicity had decreased further, when 25.0 per cent had been inactivated. If aureomycin was added to the digitalisrumen fluid mixture before incubation the inactivation was almost inhibited and after 48 hours only 4.3 per cent had been inactivated. This shows, however, that digitalis is truly inhibited by the activity of the aureomycin-sensitive microbes in the rumen fluid and that the decrease in the digitalis action is not caused by any linking to certain food particles, by proteins, or for other similar reasons. 
T a b le 1. Inactivation of digitalis in rumen fluid from sheep on different feeds.

\begin{tabular}{|c|c|c|c|c|c|c|c|}
\hline Feeding & $\begin{array}{l}\text { Lethal effect } \\
\text { in guinea } \\
\text { pigs per } 100 \\
\text { gm. body } \\
\text { weight. ml. } \\
\text { digitalis- } \\
\text { rumen fluid } \\
\text { mixture } \\
\text { injected }\end{array}$ & $\begin{array}{c}\text { Calcul- } \\
\text { ated di- } \\
\text { gitalis } \\
\text { units } \\
\text { recove- } \\
\text { red from } \\
20 \text { units } \\
\text { inserted }\end{array}$ & $\begin{array}{l}\text { Digi- } \\
\text { dita- } \\
\text { lis in- } \\
\text { activa- } \\
\text { tion } \\
\text { in } \\
\text { per } \\
\text { cent }\end{array}$ & $\begin{array}{l}\text { Cellu- } \\
\text { lose di- } \\
\text { gestion } \\
\text { hours }\end{array}$ & $\begin{array}{c}\text { Fermentation } \\
\text { gasformation } \\
\text { per minutes } \\
30 \quad 60 \\
\text { min min }\end{array}$ & $\begin{array}{l}\text { Fungi } \\
\text { Infuso- } \\
\text { ries }\end{array}$ & $\mathrm{pH}$ \\
\hline
\end{tabular}

Sheep I

Cattlefeed overfeeding

14 days

Initial value

After 48 hours

1.10

2.71

Difference

1.61

Hay and cattlefeed

and Aureomycin $35 \mathrm{mg}$ per

kgm fed to a sheep, during

2 days

Initial value

After 24 hours

0.75

0.77

0.71

After 48 hours

Difference

Sheep II

Hay 3 days after cattlefeed

Initial value

After 48 hours

0.58

0.82

Difference

0.24

After 72 hours

0.87

Difference

0.29

Same sample but Aureomycin

$0.2 \mathrm{mg}$ per $\mathrm{ml}$ added

Initial value

0.58

After 48 hours

0.63

Difference

0.05

Sheep III

Straw

Initial value

1.09

After 48 hours

1.91

Difference

0.82

Sheep IV

Hay

Initial value

0.65

After 48 hours

1.14

Difference
$++(+)$

$$
+
$$

73.1
19

16

45

510

$+(+)$

20.6

25

$\begin{array}{lll}69 & 5 & 10\end{array}$

7.5

4.3

0

5

$\begin{array}{llll} & & + \\ & & 36 & +(+)\end{array}$

$$
\begin{array}{llll}
48 & 12 & 14 & +(+) \\
& & &
\end{array}
$$


It must be kept in mind, however that the rumen contents themselves also produce a toxic effect when injected intravenously into guinea pigs (Dougherty and Cello) 1952). Exhaustion leading to death when rumen contents are injected develops gradually, however, and manifests itself as a hemorrhagic diathesis, where as death due to digitalis or a digitalis-rumen fluid mixture is much more sudden.

\section{Acknowledgements}

The writer wishes to express his thanks to Professor, M. D. Schmiterlöw for placing the facilities of the Dept. of Pharmacology, Royal Veterinary College, Stockholm, at my disposal for the main part of this work and to Professor, V. M. D. Hoflund of the Dept. of Bujatrics at the same College, for helpful advice and criticism concerning the evaluation of rumen activity.

This investigation was aided by a grant from the Finnish State.

\section{REFERENCES}

Dougherty, R. W. and Cello, R. M.: II Proc. 89th Ann. Meet. Amer. vet. med. Ass., 1952, 130-138.

Westermarck, H.: Zbl. Veterinärmed. 1956, 111, 8. p. 727/734.

\section{SUMMARY}

1) In an active rumen fluid $37.6-73.1$ per cent digitalis is inactivated in 48 hours in vitro.

2) Rumen fluid from a sheep which was fed cattlefeed in abundance was the strongest inhibitor, but rumen fluid from sheep fed straw and hay were also very active. In the first case nearly 2.5 times more digitalis-rumen fluid mixture was needed after storage at $37^{\circ} \mathrm{C}$ for 48 hours to kill a guinea pig, than was the case when digitalis was mixed with rumen fluid immediately before injection. This means that 73.1 per cent of the digitalis amount added, had been inactivated.

3) Rumen fluid inactivated by aureomycin, which was either given to the sheep before the sample was taken or added to the rumen fluid sample, lost its capacity to inhibit digitalis activity.

4) The digitalis inactivation power of a rumen fluid is correlated to the activity of the rumen microbes. 


\section{ZUSAMMENFASSUNG}

Inaktivierung von Digitalis in vitro durch die Einwirkung von Pansenmikroben vom Schaf.

1) 37.6-73.1\% zugeführter Digitalis werden in einer aktiven Pansenflüssigkeit in vitro innerhalb von 48 Stunden inaktiviert!

2) Die von einem mit Ueberschuss von Kraftfutter gefütterten Schaf entnommene Pansenflüssigkeit hemmte die Digitalis am effektivsten, während Panseninhalt vom Schaf, dem allein Stroh oder Heu verabfolgt worden war, fast ebenso wirksam war. Im ersteren Falle bedurfte es fast einer $2.5 \mathrm{mal}$ grösseren Menge einer 48 Stunden bei $37^{\circ} \mathrm{C}$ aufbewahrten Mischung von Digitalis und Pansenflüssigkeit zur Tötung von Meerschweinchen als bei direkt vor der Injektion erfolgtem Zusatz von Digitalis zur Pansenflüssigkeit. Von der zugesetzten Digitalismenge waren dann $\mathbf{7 3 . 1} \%$ inaktiviert worden.

3) Pansenflüssigkeit, die mit Aureomycin unwirksam gemacht wurde, und zwar entweder durch Eingabe dieses Antibiotikums an Schafe im Zusammenhang mit der Fütterung vor Entnahme der Pansenflüssigkeit oder nach späterer Zufuhr zur Pansenprobe, inaktivierte Digitalis nicht länger.

4) Die Inaktivierung von Digitalis in der Pansenflüssigkeit steht in Korrelation zur Mikrobenaktivität.

\section{SAMMANDRAG}

Inaktivering av digitalis in vitro genom inverkan av vom mikrober från får.

1) Mellan 37.6-73.1\% av tillförd digitalis inaktiveras i en aktiv vomvätska in vitro inom 48 timmar!

2) Vomvätskan tagen från ett får som stått på överskott av kraftfoder hämmade digitalis effektivast, medan vominnehåll från får som stått på enbart halm eller hö var nästan lika verksamt. I det förra fallet erfordrades det nära nog 2.5 ggr mera av en blandning av digitalis och vomvätska, som uppbevarats 48 timmar vid $37^{\circ} \mathrm{C}$, för att döda marsvin än när digitalis tillsatts till vomvätskan direkt före injektionen. Av den tilsatta digitalis mängden hade då $73.1 \%$ inaktiverats.

3) Vomvätska inaktiverade inte längre digitalis om den gjorts overksam med aureomycin antingen ingett åt får $i$ samband med utfodringen innan vomvätska togs eller tillfört vomprovet senare.

4) Inaktiveringen av digitalis $i$ vomvätskan står i korrelation till mikrobaktiviteten. 